Matthew Robert Shillito*

\title{
Countering Terrorist Financing via Non-Profit Organisations: Assessing why few States Comply with the International Recommendations
}

DOI 10.1515/npf-2015-0018

Abstract: This paper utilises the existing framework for analysing international "soft law" measures to examine why $83 \%$ of Financial Action Task Force members are either non-compliant or partially compliant with Special Recommendation VIII (SR.VIII) on the prevention of terrorist financing through non-profits. The paper also considers whether SR.VIII is unique amongst other FATF Recommendations in terms of its low levels of compliance.

Keywords: terrorist financing, non-profit organisations, SR.VIII, Financial Action Task Force

\section{Introduction}

Terrorist financing through non-profit organisations (NPOs) is a long standing and contentious issue. Debate has arisen as to the prevalence of such abuse, but, what has not been in contention is the susceptibility of NPOs to abuse. To that end, the Financial Action Task Force (FATF), the international standard setter for anti-money laundering and counter-terrorist financing, introduced Special Recommendation VIII (SR.VIII ${ }^{1}$ ) in 2001. It requires that countries review the adequacy of their laws and regulations which safeguard NPOs from terrorist abuse. Countries are assessed against SR.VIII using a sliding scale of compliance: compliant, largely compliant partially compliant, and non-compliant. Notably, compliance with SR.VIII has been low. Out of the 180 mutual evaluation reports examined only seven countries: Belgium, Egypt, Italy, Latvia, Oman,

1 Following the 2012 updates to the FATF Recommendations, SR.VIII is now integrated as Recommendation 8. However, due to the statistics being based on compliance with the Third Round of Mutual Evaluations, this paper refers to it as SR.VIII throughout for consistency.

*Corresponding author: Matthew Robert Shillito, School of Law and Social Justice, The Liverpool Law School, 2/045 Mulberry Court, Mulberry Street, L7 7EZ, UK, E-mail: m.shillito@liv.ac.uk 
Tunisia and USA are rated as compliant. This article will assess the reasons for the low levels of compliance.

Studies in the area are limited outside of the FATF's own publications. On the whole, they have clustered around two main issues: first, how counterterrorist financing measures impact adversely on civil society ${ }^{2}$; and second, how terrorist organisations can exploit NPOs. ${ }^{3}$ To a lesser extent, they have also considered future development of the countermeasures ${ }^{4}$; and the FATF's role as the international standard setter for counter terrorist financing measures in the non-profit sector. ${ }^{5}$

Against the above backdrop, this article will examine: first, why SR.VIII has such high levels of non-compliance; and second, whether SR.VIII is exceptional in terms of its level of partial and non-compliance. It is first important to give some context to the issue. The article will begin by introducing the threat that exists to NPOs from terrorist financers. It then turns to the international counter-terrorist financing framework, its growth following 9/11 and how SR.VIII fits the bigger framework. In order to address the issue of low compliance with SR.VIII the article will take its lead from the broader methodological approach adopted in international law commentary with regard to so-called "soft-law" and compliance. It will use a framework initially developed for international environmental law, to assess

2 See: Ben Hayes, “Counter-terrorism, 'Policing laundering' and the FATF: legalising surveillance, regulating civil society,” Transnational Institute, 2012, accessed October 08, 2014, http:// www.statewatch.org/analyses/no-171-fafp-report.pdf; Jude McCulloch and Sharon Pickering, "Suppressing the Financing of Terrorism - Proliferating State Crime, Eroding Censure and Extending Neo-Colonialism." British Journal of Criminology 45 (2005): 470; Jude Howell, "Civil society, Aid, and Security Post-9/11." International Journal of Not-for-Profit Law 12 (2010), accessed October 13, 2014, http://www.icnl.org/research/journal/vol12iss4/special_2.htm; Mark Sidel, "Counter-terrorism and the Regulation of Civil Society in the USA.” Development and Change 41 (2010), 293-312; and Mark Sidel, Regulation of the Voluntary Sector, Freedom and Security in an Era of Uncertainty (Abingdon, UK: Routledge, 2010).

3 See: Sidel, above n 2; Robert Looney, "The Mirage of Terrorist Financing: The Case of Islamic Charities.” Strategic Insights 5(3) (2006), accessed October 13, 2014, http://www.isn.ethz.ch/DigitalLibrary/Publications/Detail/?ots591=0c54e3b3-1e9c-be1e-2c24-a6a8c7060233\&lng=en\&id=32195; and Matthew Levitt, "Charitable Organisations and Terrorist Financing: A War on Terror StatusCheck.” The Washington Institute, March 19, 2004, accessed October 13, 2014, http://www.washing toninstitute.org/policy-analysis/view/charitable-organizations-and-terrorist-financing-a-war-on-ter ror-status-che.

4 See: Looney, above n 3; and Wouter H. Muller, "Charities and Anti-Money Laundering: Is a 'Seal of Approval' the Answer?” Trusts \& Trustees 14(5) (2008): 259-71, 263.

5 See: Ben Hayes, "From Countering Financial Crime to Criminalising Civil society: How the FATF Overstepped the Mark.” Open Society Foundations, May 8, 2013, accessed October 09, 2014, http://www.opensocietyfoundations.org/voices/countering-financial-crime-criminalizingcivil-society-how-fatf-overstepped-mark. 
compliance with SR.VIII. Subsection A of this will focus on factors affecting compliance, namely: "characteristics of the activity targeted by the instrument", "characteristics of the agreement", "the international environment", and "national characteristics". Subsection B turns to "compliance as a function of national intent and capacity.” Finally, compliance with SR.VIII will be compared with other Recommendations in order to address trends, and to see where it fits in the broader anti-money laundering and counter-terrorist financing landscape.

\section{Terrorist Financing and the Non-profit Sector}

The FATF and the World Bank, through various reports and working papers, have highlighted numerous vulnerabilities that make NPOs susceptible to terrorist abuse. First, NPOs enjoy a great deal of public trust, such that their transactions and activities are rarely questioned. ${ }^{6}$ This provides cover for terrorist organisations to operate. Second, they may have access to considerable funds and are often cash intensive, so not only are they capable of raising funds for terrorist purposes, they also provide cover for illicit transactions. ${ }^{7}$ Third, NPOs can have a global presence involving transactions in or to high risk jurisdictions. ${ }^{8}$ The volume of legitimate transactions acts to mask the illegitimate ones. Fourth, NPOs may use alternative financial instruments. ${ }^{9}$ Irrespective of whether they are: longstanding (wire transfers); or newly emerging (mobile payments or Bitcoin); they provide a further layer of cover for terrorists. ${ }^{10}$ Fifth, they can have little or no regulatory oversight depending on their form and the country in which they are operational. ${ }^{11}$ This provides a risk-reduced environment for

6 FATF, Report on Money Laundering Typologies 2002-2003, February 2003, http://www.fatfgafi.org/media/fatf/documents/reports/2002_2003_ML_Typologies_ENG.pdf; and, Ipsos MORI Social Research Institute, Public Trust and Confidence in Charities, June 2012, https://www. ipsos-mori.com/Assets/Docs/Publications/sri-charities-charity-commission-public-trust-and-con fidence-june-2012.pdf.

7 FATF, Terrorist Financing, February 2008, http://www.fatf-gafi.org/media/fatf/documents/ reports/FATF\%20Terrorist\%20Financing\%20Typologies\%20Report.pdf, 11.

8 Ibid, at 11.

9 FATF, Report on Money Laundering Typologies 2003-2004, February 2004, http://www.fatfgafi.org/media/fatf/documents/reports/2003_2004_ML_Typologies_ENG.pdf, 11.

10 These methods tend to involve the movement of funds in a faster and cheaper way, without face to face action, across borders and often with anonymity. Therefore to the terrorist financer NPOs who engage in the use of these alternate instruments are appealing to abuse.

11 World Bank, Non-profit Organisations and the Combatting of Terrorism Financing: A Proportionate Response (Working Paper, No. 208, 2010) Ch. 3. 
terrorist financers to operate in. Each of these factors are a challenge for counterterrorist financing regulators, however, their cumulative and combined effects make the abuse of NPOs an area of heightened risk and regulatory interest.

Despite the vulnerabilities there is much debate as to the prevalence of terrorist abuse of the NPO sector: on the one hand, it is claimed that there are very few instances of terrorist financing in the NPO sector ${ }^{12}$; on the other, there are those who claim instances of terrorist financing in the NPO sector are quite high. ${ }^{13}$ Examples of abuse tend to lack tangible proof. The head of the England and Wales Charity Commission has noted that some of the money going to help millions of refugees in Syria is undoubtedly being channelled to extremist groups. ${ }^{14}$ The Commissioner of the Metropolitan Police has suggested that money donated in charity boxes may be funding terrorism..$^{15}$ On top of this, the England and Wales Charity Commission has put 55 unnamed groups on a watch list in the last 2 years due to their suspected Muslim extremist links. ${ }^{16}$

12 For examples see: Ben Hayes, "How International Rules on Countering the Financing of Terrorism Impact Civil Society.” Transnational Institute, 2013, http://www.tni.org/briefing/howinternational-rules-countering-financing-terrorism-impact-civil-society; European Commission and Matrix insight, Study to Assess the Extent of Abuse of Non-Profit Organisations for Financial Criminal Purposes at EU Level, April 2008, http://ec.europa.eu/home-affairs/doc centre/terrorism/docs/study_abuse_non_profit_orgs_for_financial_criminal_purposes_avril09. pdf; Charity Commission, Charity Commission Counter-Terrorism Strategy, July 2008, revised April 2012, http://www.charitycommission.gov.uk/media/89498/ctstext.pdf; Council on Foundations Ends Effort to Revise Anti-Terrorism Financing Guidelines' Philanthropy News Digest, November 24, 2010, http://foundationcenter.org/pnd/news/story.jhtml?id=315500008. 13 For examples see: FATF, Global Money Laundering and Terrorist Financing Threat Assessment, July 2010, http://www.fatf-gafi.org/media/fatf/documents/reports/Global\% 20Threat\%20assessment.pdf; FATF, Best Practices: Combating the Abuse of Non-Profit Organisations (Recommendation 8), June 2013, http://www.fatf-gafi.org/media/fatf/documents/ reports/Combating_the_abuse_of_NPOs_Rec8.pdf; Howell, above n 2; “The Iceberg Beneath the Charity: Probes Uncover Submerged Links Between Charities and Terrorists.” The Economist, March 13, 2003, http://www.economist.com/node/1632610; Peter Clarke, "Charity Cash Going to Syrian Terror Groups.” The Telegraph, October 4, 2013, http://www.telegraph.co.uk/news/world news/middleeast/syria/10357537/Charity-cash-going-to-Syrian-terror-groups.html.

14 Christopher Hope, "Charity Cash Going to Syrian Terror Groups.” The Telegraph, October 4, 2013, accessed November 28, 2014, http://www.telegraph.co.uk/news/worldnews/middleeast/ syria/10357537/Charity-cash-going-to-Syrian-terror-groups.html.

15 David Brown, “Charity Boxes May Be Funding Terrorism.” The Times, November 24, 2014, accessed November 28, 2014, http://www.thetimes.co.uk/tto/news/uk/article4276077.ece? shareToken $=935 f 49$ ba6b131b40db700910a86cb22b.

16 Dominic Kennedy, “Charities Suspected of Muslim Extremist Links.” The Times, November 17, 2014. Accessed November 28, 2014, http://www.thetimes.co.uk/tto/news/politics/arti cle4269818.ece?shareToken=72f3f3c824f44943f7da6f2c2a90462f. 
What is clear is that there is ongoing concern about the potential for NPOs to be abused, whether knowingly or otherwise, by terrorist organisations.

It is this potential threat, rather than actual instances, which drives international focus on the sector. The above vulnerabilities explain why NPOs are susceptible to abuse by terrorist financers. The importance of international action in the area is heightened by the fact that the financial sector and money service businesses are under increasing scrutiny and regulatory attention with the majority of the FATF 40 Recommendations relating to them. If measures were not introduced in the non-profit sector then it would be an easy target for terrorist financers to exploit. Further, NPOs operate in a unique environment; they are seen as a vital component of both the global and domestic economy, which complements the work of the government and business sectors in supplying a broad range of services and provisions. ${ }^{17}$ Further, David Aufhauser (General Counsel of America's Treasury department) has stated that the networks of charities often reach out to the world's "breeding grounds for terrorists". ${ }^{18}$ The World Bank has acknowledged the need for regulatory involvement in the area, however they have also stressed the need for proportionality: "NPOs are seen as a force for good that need to be protected, as opposed to being unnecessarily curtailed, and that is why we seek to protect their freedoms." 19 Therefore the international response has to focus across a range of sectors, the international framework to counter terrorist financing is only as strong as its weakest component, hence the need for a specific response focussing on NPOs.

\section{The International Counter Terrorist Financing Framework}

The risk of terrorist abuse of NPOs is not a new issue, 20 years ago the G7 called for measures to combat those organisations which falsely claim to have "charitable, social or cultural goals" or which are also engaged in unlawful activities such as illicit arms trafficking, drug dealing, and racketeering. ${ }^{20}$ However, prior to $9 / 11$ this area was not at the forefront of the international communities mind.

17 FATF, Best Practices: Combating the Abuse of Non-Profit Organisations (Recommendation 8), June 2013, http://www.fatf-gafi.org/media/fatf/documents/reports/Combating_the_abuse_of_ NPOs_Rec8.pdf, 5 .

18 The Economist, above n 13.

19 See World Bank, above n 11, at Ch. 3.

20 G7, 'Ministerial Conference on Terrorism' (G8, July 30, 1996), http://www.g8.utoronto.ca/ terrorism/terror25.htm (accessed November 26, 2014). 
Although the 1999 International Convention for the Suppression of Terrorist Financing was in place, placing counter terrorist financing at the head of the UN's approach to tackling terrorism, it was only ratified by four countries. ${ }^{21}$

Post-9/11 the counter-terrorist financing international landscape laid its roots. ${ }^{22}$ International attention was refocused, with the UN Security Council taking a firm lead; they became the focal point of discussions and the forum for the adoption of measures against terrorism. ${ }^{23}$ Within 5 days of $9 / 11 \mathrm{UN}$ Security Council Resolution 1373 was put into place. ${ }^{24}$ The benefit of the Security Council Resolution being that it is immediately binding on all UN member states. The Resolution essentially amounted to an obligation to apply the operative parts of the UN International Convention for the Suppression of the Financing of Terrorism. ${ }^{25}$ It also provided for the setting up of the Counter Terrorism Committee to monitor the implementation of the Resolution by the states. In April 2002, the International Convention for the Suppression of the Financing of Terrorism became effective, giving the measures contained in Resolution 1373 a permanent existence. By the end of June 2006 the Convention had 154 signatories highlighting the increased political will to counter terrorist financing. ${ }^{26}$ This formed the key legal framework in combatting terrorist financing, requiring signatories to adopt domestic legislation to criminalise and punish terrorist financing, licence or register all money transmitting services, detect and control the physical cross-border transportation of currency and negotiable instruments, and develop and implement internal controls to prevent financial institutions from being used to transfer funds to terrorists. ${ }^{27}$

The cornerstone of the UN strategy in countering terrorist financing is what it refers to as "targeted sanctions (or smart sanctions)". Targeted Sanctions "breach the state veil" by identifying individuals and subjecting them to pressure in the hope that they will change their behaviour. ${ }^{28}$ There is no widely

21 Olivia Bosch and Peter van Ham, Global Non-proliferation and Counter-Terrorism: The Impact of UNSCR 1540 (Baltimore: Royal institute of international affairs, Brooking Institution Press, 2007), 30.

22 Mark Sidel, Critical Approaches to Law: Regulation of the Voluntary Sector (Routledge, 2010), 7.

23 Ilias Bantekas, "The International Law of Terrorist Financing." The American Society of International Law 97(2) (2003): 315.

24 Jimmy Gurule, Unfunding Terror: The Legal Response to the Financing of Terrorism (Cheltenham: Edward Elgar, 2008), 6.

25 Iain Cameron, "European Union Anti-Terrorist Blacklisting." Human Rights Law Review 3 (2003): 225, 229.

26 See Bosch and van Ham, above n 21, at 30.

27 See Gurule, above n 24, at 10.

28 See Cameron, above n 25, at 226 
accepted definition of "targeted sanctions" but Cameron has stated that it includes the following measures: the freezing of financial assets; the suspension of credits and aid; the denial and limitation of access to foreign financial markets; trade embargoes on arms and luxury goods; flight bans and the denial of international travel, visas and educational opportunities. ${ }^{29}$ They are designed to force compliance with a UN Security Council Resolution from specific individuals while trying to avoid any negative impact on the rest of the population in the targeted state. ${ }^{30}$ The EU has embraced this strategy and also has empowered itself to amend the list of persons to whom sanctions apply. ${ }^{31}$ There is no general agreement as to the effectiveness of targeted sanctions. ${ }^{32}$

\section{The Financial Action Task Force}

The above UN measures only represent one side of the international effort to counter terrorist financing; the FATF and its 40 Recommendations also play a significant role. The FATF Recommendations are intended to play a complimentary role, alongside the UN measures, in the international counter-terrorist financing and anti-money laundering framework. It is the measures introduced by the FATF and Special Recommendation VIII in particular on which this article focuses. Whilst the above UN measures are imperative in the fight against terrorist financing, it is the FATF that introduced measures that are specific to the preventing the abuse of non-profits.

The FATF is an intergovernmental body and acts as the international standard setter for anti-money laundering and counter-terrorist financing, through its 40 Recommendations. Its mandate operates in eight year cycles and currently

29 Iain Cameron, "UN Targeted Sanctions, Legal Safeguards and the European Convention on Human Rights." Nordic Journal of International Law 72 (2003): 159, 160.

30 William Vlcek, "Hitting the Right Target: EU and Security Coucil Pursuit of Terrorist Financing." Critical Studies on Terrorism 2(2) (2009): 275, 277.

31 Nettesheim, "U.N. Sanctions Against Individuals - A Challenge to the Architecture of European Union.” Common Market Law Review 44 (2007): 567, 572.

32 For arguments see: Margaret P. Doxey, International Sanctions in Contemporary Perspective (2nd edn., New York: St. Martins Press, 1996); Peter Wallensteen, A Century of Economic Sanctions: A Field Revisited, Uppsala Peace Research Papers No. 1 (Sweden: Department of Peace and Conflict Research, Uppsala University, 2000); Robert A. Pape, "Why Economic Sanctions Do Not Work." International Security 22 (1997): 90-136; Kimberly A. Elliott, "The Sanctions Glass: Half Full or Completely Empty?” International Security 23 (1998): 50-65, and David A. Baldwin, "The Sanctions Debate and the Logic of Choice." International Security 24 (1999): 80-107. 
runs until the end of December 2020. ${ }^{33}$ As long as there is sufficient political will this will continue to be renewed. Traditionally, its mandate has focussed on the financial sector; however, over time it has expanded to the non-profit sector and money service businesses.

At present there are over 180 countries in which the Recommendations are implemented and assessed. ${ }^{34}$ Only 34 countries are direct members of the FATF, the rest are members of FATF-Style Regional Bodies (FSRB's). ${ }^{35}$ The FSRB's have the status of "associate" members of FATF which affords them participation within FATF. ${ }^{36}$ This status grants them: access for FSRB delegations to all FATF meetings, access for FSRB member jurisdictions to FATF working group meetings, access for FSRB member jurisdictions to FATF Plenary meetings, Access to FATF documents, input on FATF discussions and decisions, assistance from FATF, right to participate in FATF mutual evaluations, FATF to further enhance joint exercises. ${ }^{37}$

The Recommendations provide a set of global anti-money laundering and counter-terrorist financing standards that members of the FATF and FSRB's should strive to achieve. They are non-binding, and the principles that they promote are open to interpretation by states as to how best to implement them into their national law. Countries have diverse legal, administrative and operational frameworks, and as such a one size fits all approach to anti-money laundering and counter-terrorist financing would not work.

Special Recommendation VIII represents the international guidance on applying counter terrorist financing measures specifically to the non-profit sector. It provides suggestions on what countries should implement to avoid abuse of the sector. Special Recommendation VIII states: "countries should review the adequacy of laws and regulations that relate to entities that can be abused for the financing of terrorism", ${ }^{38}$ making specific reference to NPOs.

33 FATF, Financial Action Task Force Mandate 2012-2020, April 20, 2012, http://www.fatf-gafi. org/media/fatf/documents/FINAL\%20FATF\%20MANDATE\%202012-2020.pdf, 8.

34 See: FATF Members and Observers, http://www.fatf-gafi.org/pages/aboutus/membersandob servers/.

35 Ibid.

36 FATF, Annual Report: 2004-2005, June 23, 2005, http://www.fatf-gafi.org/media/fatf/docu ments/reports/2004\%202005\%20ENG.pdf, Forward.

37 FATF, Annual Report: 2009-2010, June 2010, http://www.fatf-gafi.org/media/fatf/docu ments/reports/2009\%202010\%20ENG.pdf, Forward.

38 FATF, International Standards on Combating Money Laundering and the Financing of Terrorism \& Proliferation, February 2012, http://www.fatf-gafi.org/media/fatf/documents/recom mendations/pdfs/FATF_Recommendations.pdf, 13. 
The Recommendation envisages three ways that NPOs could be misused: exploitation by terrorist organisations posing as legitimate entities, to exploit legitimate entities as conduits for terrorist financing, and to conceal or obscure the clandestine diversion of funds (intended for legitimate purposes) to terrorist organisations. ${ }^{39}$ SR.VIII, perhaps unsurprisingly given its goal, is broad in its scope; covering both the knowing and unknowing abuse of NPOs for the purposes of terrorist financing. The Recommendation is accompanied by an Interpretative Note and a Best Practices paper which restricts its application and gives guidance on how to apply it. The Interpretative Note expands on SR. VIII by providing both the "objective and general principles" and the "measures" that should be introduced; whilst the Best Practices paper provides the FATF's proposals on compliance with SR.VIII. ${ }^{40}$ The Paper undergoes sporadic updates, the last of which was in June 2013, as the understanding of how terrorist financers abuse NPOs develops. ${ }^{41}$ It provides that FATF members should have measures in place which: compel the NPO to present full program budgets that account for all program expenses; ${ }^{42}$ encourage the use of the formal financial system; ${ }^{43}$ ensure that NPOs are completing due diligence; ${ }^{44}$ and ensure NPOs are honestly representing their cause. ${ }^{45}$ Despite the numerous updates to the 40 Recommendations since 2001, the wording of Recommendation 8 has remained static from its infancy as SR.VIII. Instead, numerous changes have been made to the Interpretative Note and the Best Practices paper.

In order to ensure compliance with the FATF Recommendations, there is an initial self-assessment followed up by a Mutual Evaluation Report. States are assessed on a sliding scale of descriptors for each Recommendation: compliant, largely compliant, partially compliant, and non-compliant. Each evaluation is completed by a team comprised of 4-6 experts with legal, financial and law enforcement expertise and two members of the FATF Secretariat. ${ }^{46}$ This is significant as it allows representatives of other states to see good practices and deficiencies in the evaluated countries system, and then make changes to

39 Ibid, at 13.

40 The Best Practices paper undergoes sporadic updates as understanding of how terrorist financers abuse NPOs develops, the last of these updates was in June 2013.

41 Ibid.

42 See FATF, above $\mathrm{n} 17$, at 7.

43 Ibid, at 7.

$44 \mathrm{Ibid}$, at 8 .

45 Ibid, at 7.

46 See FATF Annual Report: 2009-2010, above n 37, at 19. 
their own. The whole mutual evaluation process takes about a year even though the onsite visit only takes three days. ${ }^{47}$ The constant cycle of review, assessment and guidance emerging from these reports provides a positive environment in which anti-money laundering and counter-terrorist financing measures can be developed and improved. As the Recommendations are periodically updated, the levels that countries are aiming for in terms of compliance are not fixed.

Following the mutual evaluation of the member state, if there are serious deficiencies highlighted then the FATF will take appropriate follow up action. The initial step that the FATF is likely to take is to send a letter to the member state explaining the deficiency, to be followed up by a delegation led by the FATF President to ensure deficiencies in the letter are being addressed. ${ }^{48}$ They will also order the country to submit a follow up report to the FATF plenary, within two years of the initial evaluation, noting the progress made on the deficiencies. $^{49}$ In more serious cases, or where that measure has not worked, the FATF will place the member state in question on their High Risk and Non Cooperative Countries and Territories (NCCT) list. This list provides a convenient record of all countries that are having issues meeting the FATF standards. Its aim is to shame countries into taking the required action to improve their AML and CFT framework. ${ }^{50}$ The list is available on the FATF website for all to see. ${ }^{51}$ Alongside this list the FATF will also urge financial institutions worldwide to scrutinise business relations and transactions with persons, companies, and financial institutions domicile in the relevant country. ${ }^{52}$ The issue is that these follow-up measures are not applied where there is a deficiency in one aspect of the FATF 40 Recommendations. Indeed they have never been applied for deficiencies relating to SR.VIII.

47 N. Moloney, "The European Securities and Markets Authority and Institutional Design for the EU Financial Market - A Tale of Two Competences: Part 2: Rules in Action.” European Business Organization Law Review 12(2) (2011): 177, 197.

48 FATF, Financial Action Task Force on Money Laundering: Annual Report 2012-2013, June 2013, http://www.fatf-gafi.org/media/fatf/documents/brochuresannualreports/FATF\%20Annual \%20Report\%202012\%202013.pdf.

49 Ibid, at 19.

50 FATF, 20 years of the FATF Recommendations 1990-2010, June 2010, http://www.cbr.ru/ today/anti_legalisation/fatf/20_years.pdf, 7.

51 See: High-risk and non-cooperative jurisdictions, http://www.fatf-gafi.org/topics/high-ris kandnon-cooperativejurisdictions/.

52 FATF, Financial Action Task Force on Money Laundering: Annual Report 1995-1996, June 1996, http://www.fatf-gafi.org/media/fatf/documents/reports/1995\%201996\%20ENG.pdf. 


\section{5 "Soft Law" and Compliance}

There is no universally accepted definition of "soft law". Debate has centred on whether it is: law, quasi law, or not law at all. ${ }^{53}$ It is beyond the scope of this article to engage in this argument. However, for the purposes of being able to analyse the FATF Recommendations under the existing "soft law" and compliance framework, some guidance will be given as to what can amount to "soft law".

Shelton has suggested that "soft law" refers to: "an international instrument other than a treaty that contains principles, norms, standards, or other statements of expected behaviour." 54 In other words, normative provisions contained in non-binding texts. ${ }^{55}$ Johnston states that such agreements are in frequent use on the international stage. ${ }^{56}$ Further, he notes: their status as "soft-law" does not necessarily give them less impact than legally binding instruments. ${ }^{57}$ Shelton, in support of this, confirms that the use of political pressure can be used to induce others to change their practices. ${ }^{58}$ But, she adds: "generally, however, states cannot demand that others conform to legal norms the latter have not accepted."59 They are used over other forms of agreement due to the advantages that they offer, namely: their speed of adoption and because they are viewed as being useful for technical matters that may need rapid or repeated revision. ${ }^{60}$ They can often function as an authoritative way to allow treaty parties to resolve ambiguities in a binding text or fill in gaps. From this, it is clear that the FATF

53 See for debates: Dinah Shelton, Commitment and Compliance: The Role of Non-binding Norms in the International Legal System (1st edn., OUP, 2000); Samuel A. Bleicher, "The Legal Significance of Re-citation of General Assembly Resolutions.” AJIL 63 (1969): 444; Hiram E. Chodosh, "Neither Treaty nor Custom: The Emergence of Declarative International Law." Texas International Law Journal 26 (1991): 87; Rosalyn Higgins, "The Role of Resolutions of International Organisations in the Process of Creating Norms in the International System," in International Law and the International System, ed. William.E. Butler (1st edn., Martinus Nijhoff Publishers, 1987); Fredric L. Kirgis Jr., "Customs on a Sliding Scale.” AJIL 81 (1987): 146; and Christopher C. Joyner, "U.N. General Assembly Resolutions and International Law: Rethinking the Contemporary Dynamics of Norm-Creation." California Western International Law Journal 11 (1981): 445.

54 Dinah Shelton, "Normative Hierarchy in International Law." The American Journal of International Law 100 (2006): 291, 319.

55 Ibid, at 291.

56 Douglas M. Johnston, Consent and Commitment in the World Community: The Classification and Analysis of International Instruments (1st edn., Brill| Nijhoff, 1997).

57 Ibid.

58 See Shelton, above n 54, at 319.

59 Ibid, at 319.

60 Ibid, at 322. 
Recommendations can be considered "soft law". As noted above, they provide a set of broad principles permit countries to implement them how they see fit. The FATF, because of their status, do not have the power to adopt binding texts.

The analytical approach adopted forthwith is based on the framework developed for assessing compliance with international environmental law. ${ }^{61}$ Brown Weiss and Shelton have expanded the use of this framework to "soft law" in general. ${ }^{62}$ There are two strands to the assessment: first, it uses four broad categories of variables that can explain compliance; and second, it looks at national characteristics. For the first strand, the four categories of variables are: characteristics of the activity involved; characteristics of the agreements; the international environment; and factors involving the countries. ${ }^{63}$ Whilst, the national characteristics are broken down into: intent and capacity. ${ }^{64}$

\subsection{Factors Affecting Compliance}

The first variable, "characteristics of the activity targeted by the instrument", focusses on whether the agreement is binding or non-binding. As previously identified, the FATF Recommendations are non-binding law; they receive their force from political pressure and constant evaluation of FATF member states. Previous studies of non-binding agreements have found that "the fewer the number of actors involved, the easier to regulate". ${ }^{65} 187$ countries were members of either the FATF or a FATF-Style Regional Body during the third round of Mutual Evaluations. Significantly, the number of members is a factor which would affect all Recommendations equally. It cannot therefore, explain compliance with SR.VIII in isolation. The fact that measures introduced by the UN are

61 See: Edith Brown Weiss and Harold K. Jacobson, Engaging Countries: Strengthening Compliance with International Environmental Accords (1st edn., MIT Press, 1999); Abram Chayes and Antonia Handler Chayes, The New Sovereignty: Compliance with International Regulatory Agreements (1st edn., Harvard University Press, 1998); David G. Victor, Kal Raustiala, and Eugene B. Skolnikoff, The Implementation and Effectiveness of International Environmental Commitments: Theory and Practice (1st edn., MIT Press, 1998); Harold Hongju Koh, “Why Do Nations Obey International Law?” The Yale Law Journal 106 (1997): 2599; Wolfrum Rudigger, Enforcing Environmental Standards: Economic Mechanisms as Viable Means (1st edn., Springer, 1996).

62 Edith Brown Weiss and Dinah Shelton, "Conclusions: Understanding Compliance with Soft Law," in Commitment and Compliance: The Role of Non-binding Norms in the International Legal System, ed. Dinah Shelton (OUP, 2003).

63 Brown Weiss and Jacobson, above n 61.

64 Ibid.

65 See Brown Weiss and Shelton, above n 62, at 548. 
hard law may improve compliance with some Recommendations, particularly those surrounding criminalisation and confiscation, however there is no UN overlap with SR.VIII. What will have an impact on compliance levels is a state's attitude towards an individual Recommendation; this is assessed under other variables below.

The second variable, "characteristics of the agreement", focusses on the agreement itself and factors inducing states to comply. Characteristics of the Recommendation which will be considered under this variable include: whether it is equitable; whether it is clear and understandable; and what mechanisms are used to police compliance.

Arguably, the most important characteristic for an international agreement is that states perceive it as being equitable. ${ }^{66}$ On balance, the advantages of committing to the agreement need to outweigh the burdens of complying. ${ }^{67}$ Hayes has stated that SR.VIII is "too burdensome as it creates onerous rules and regulations, which restricted activities and thus the operational and political space of NPOs." ${ }^{68}$ That only seven of the 180 countries examined are rated as compliant would appear to offer further support to Hayes' assertion. Ordinarily, a high volume of members signed up to an agreement would indicate that they were content with the balance. However as they have no freedom to choose which Recommendations they comply with, this means that volume of members is not indicative of satisfaction with any individual Recommendation.

Further the agreement needs to be "clear and capable of compliance". SR. VIII's Interpretative Note and Best Practices paper impose a plethora of obligations and expectations which add complexity. The general principles underpinning the Interpretative Note to SR.VIII cannot be questioned; however, due to the volume of obligations it imposes, it places heavy demands on the limited resources of FATF member states. The Best Practices paper further adds to this burden; it recommends that states implement a host of specific measures, including the licensing or registration of non-profits, increased police scrutiny of non-profit sector and strict reporting and vetting requirements. Hayes notes that together, the Interpretative Note and the Best Practices paper "add up to a recipe for civil society repression." ${ }^{69}$ If the Best Practices paper and

66 Harold K. Jacobson and Edith Brown Weiss, "Assessing the Record and Designing Strategies to Engage Countries," in Engaging Countries: Strengthening Compliance with International Environmental Accords, ed. Edith Brown Weiss and Harold K. Jacobson (1st edn., Massachusetts, United States: MIT Press, 1999), 552-53.

67 Christian Tomuschat, Obligations Arising for States without or Against Their Will (1993) 241 Recueil des Cours, 361.

68 See Hayes, above n 2, at 6.

69 See Hayes, above n 5. 
Interpretative Note are placing too onerous a burden on states, then it is understandable why compliance with SR.VIII is low. To an extent the FATF have attempted to alleviate the burden: "measures adopted by countries to protect the NPO sector from terrorist abuse should not disrupt or discourage legitimate charitable activities."70 This could be seen as recognition by the FATF that states cannot achieve all of the obligations set out. However, the usefulness of the safeguard is questionable, Hayes observes: "there is nothing further in the lengthy guidance on how to best protect the freedom of association and expression in the delicate realm of non-profit/civil society regulation."71 Without further guidance on achieving an appropriate balance between implementation of obligations and ensuring freedom of association and expression, then states will be unsure as to how far they need to go to comply. Over time, the FATF has sought to improve the Interpretative Note and Best Practices paper through updates however, the above deficiencies still remain.

Alongside the preceding "characteristics of the agreement" there is still a significant role to be played by mechanisms that induce compliance. These mechanisms were detailed in section IV. One of the most significant is the mutual evaluation report, Chinkin has argued that: "ordinarily, reported international assessments should be enough to ensure compliance with a given soft law measure."72 This is partly because they highlight deficiencies that may not have been apparent, and partly because of the peer pressure they place on states to comply. On top of this, any best practices are flagged for use by other states. However this is clearly not the case for SR.VIII, 83\% of countries are rated as non-compliant or partially compliant with SR.VIII (with only $17 \%$ being compliant or largely compliant).

Alongside the mutual evaluation reports, the FATF's High Risk and NCCT list is at the heart of their efforts to ensure compliance with the Recommendations. Other international bodies, responsible for oversight of "soft law" measures, have found such naming and shaming mechanisms to be an effective method of improving compliance. ${ }^{73}$ In conjunction with the naming and shaming, the FATF

70 See the Interpretative Note to Recommendation 8, Section B3(b); FATF, above $n$ 38; and FATF, above $n 13$.

71 See Hayes, above $n 5$.

72 C. M. Chinkin, "The Challenge of Soft Law: Development and Change in International Law.” International and Comparative Law Quarterly 38 (1989): 850, 862-63.

73 FSB, Framework for strengthening Adherence to international Standards, January 2010. On the "hardening" effect of this commitment to peer review: D. W. Arner and M. W. Taylor, "The Global Financial Crises and the Financial Stability Board: Hardening the Soft Law of International Financial Regulation?" University of New South Wales Law Journal 32 (2009): 488, 498-500. 
also urge financial institutions worldwide to scrutinize business relations and transactions with person, companies, and financial institutions domiciled in the non-compliant country. ${ }^{74}$ This step has also been ineffective in terms of SR.VIII, as it has not been implemented due partial or non-compliance with that specific Recommendation. At present such sanctions require several serious anti-money laundering ad counter-terrorist financing deficiencies to be present. It would also reduce the effectiveness of the High Risk and NCCT list if the $83 \%$ of countries that are non-compliant or partially compliant with SR.VIII were included on it.

It is, however, worthy of note that we have not seen the full effect of these measures yet. The third round of Mutual Evaluation reports present the first time that the FATF counter-terrorist financing measures in the NPO sector have come under the assessment microscope.

The third variable "the international environment" plays a significant role in ensuring compliance with "soft law" measures. Indeed, Jacobson and Brown Weiss have expressed the view that the international environment "may well be the most important factor explaining the acceleration in the secular trend toward improved implementation and compliance..."75 They identified a number of factors which contribute to this variable: international conferences, global media and public opinion, international nongovernmental organisations, international financial institutions, and international organisations. ${ }^{76}$

The first factor to be looked at in terms of the international environment is role of the FATF's involvement with NPO sector. SR.VIII represents its only foray into the sector. The FATF's objective is self-defined as; "setting standards and promoting effective implementation of legal, regulatory and operational measures for combatting money laundering, terrorist financing and other related threats to the integrity of the international financial system." ${ }^{27}$ Their focus is on the financial system, their work with regards to NPOs can only be explained by virtue of the fact that they can be abused for money laundering and terrorist financing, and they may exploit the financial sector in doing so.

Prior to April 2013, all measures were implemented and imposed whilst having only limited engagement with the NPO sector. ${ }^{78}$ This is in contrast to

74 FATF, above n 52.

75 See Brown Weiss and Jacobson, above n 61, at 512-15.

76 See Brown Weiss and Shelton, above n 62, at 549.

77 FATF, “About us," http://www.fatf-gafi.org/pages/aboutus/.

78 FATF, Consultation and Dialogue with Non-Profit Organisations (2013), http://www.fatf-gafi. org/topics/fatfrecommendations/documents/consultationanddialoguewithnon-profitorganisa tions.html. 
Recommendations with a focus on the financial sector where they engage with various stakeholders. ${ }^{79}$ Failure to engage sufficiently with the sector has a number of negative effects. First and foremost, it reduces the FATF ability to enhance its knowledge base and gain feedback. As previously noted SR.VIII is the FATF's only foray into the NPO sector, they would therefore benefit from more sustained engagement with the sector. Second, due to the lack of engagement the Recommendation comes across as "top down" which may add to pre-existing doubts about its effectiveness. The NPO sector has its own unique challenges of which the FATF may not appreciate the subtleties. NPOs have to focus on where the money has come from and where it is going to, both are equally important. Further when making sure that their funds have reached the intended beneficiary they also have to ensure that the project has been carried out, that the beneficiaries are real, that the beneficiaries have received the funds that were sent for them, and that all the funds, assets and premises are accounted for. ${ }^{80}$ This highlights the challenges faced by NPOs, and the reason that a risk-based approach needs to be in place. The lack of influence of NPOs on the international framework was highlighted in the last FATF periodic review. Launched in October 2010, with requests for submissions from interested parties, the review was based on 55 questions in a 521 page document, but there was no mention of SR VIII. As a result, NPOs were effectively excluded from the review process. ${ }^{81}$

Since the third round of Mutual Evaluation Reports there has been some recognition that there needs to be a greater contribution from the NPO sector in developing the Recommendation. The World Bank has stated that the contribution of the NPO sector should be used to its full advantage. ${ }^{82}$ The FATF held a consultation and dialogue meeting with NPOs with a view to getting the input of the NPO sector into reforming the "FATF Best Practices paper on Combatting the Abuse of Non-profit Organisations" and eventually into updating SR.VIII. ${ }^{83}$

79 See: FATF, Annual Report 2013-2014, 2014, http://www.fatf-gafi.org/media/fatf/documents/ brochuresannualreports/FATF\%20Annual\%20report\%202013-2014.pdf for information on the FATF's engagement with the Wolfsberg Group, as well as initiatives such as the 'Private Sector Consultative Forum' which engages participants representing the financial sector and other businesses and professions that are covered by the 40 Recommendations.

80 See; FATF, above n 13.

81 FATF, Consultation on proposed changes to the FATF Standards: Compilation of Responses from NGOs and Individuals, 2011, http://www.fatf-gafi.org/media/fatf/documents/publicconsul tation/First $\% 20$ public\%20consultation\%20document $\% 20$ responses $\% 20$ non $\% 20$ gov $\% 20$ and $\%$ 20individuals.pdf.

82 See World Bank, above n 17, at ix.

83 FATF, Consultation and Dialogue with Non-Profit Organisations, http://www.fatf-gafi.org/ documents/news/npo-consultation-march-2015.html. 
This new approach can only be seen as a positive step, and will undoubtedly see improvements in compliance as the Recommendation starts to reflect what the sector sees as achievable and in turn FATF member states focus on implementation. Of course the consultation will only lead to more compliance if the FATF listen to and implement changes based on the feedback given by NPOs. It has also been noted that in the long term the FATF will perform more typologies work in the area, ${ }^{84}$ this will improve the FATF's own knowledge and expertise in the area.

The FATF's lack of knowledge and understanding of the NPO sector is compounded by the lack of international institutions and non-governmental organisations to engage with. There is a deficiency, both of: an international body overseeing the NPO sector, and of collective lobbying groups.

Unlike other sectors the FATF engages with, the NPO sector does not have an international regulator. The closest body to one is the International Committee on Fundraising Organisations (ICFO). However, its membership is very different to that of an international regulator. Whilst it has members from: the US, Canada, the Netherlands, France, Mexico, Germany, Italy, Spain, Norway, Switzerland, Sweden, Taiwan, China, Luxemburg, and Belgium, ${ }^{85}$ these are only small specific accrediting bodies. ${ }^{86}$ It does not have the same influence that the World Bank has for instance, and so would be of less use to the FATF. Further, it raises issues with regards to disseminating best practices and sharing emerging typologies and threats. An international charity regulator would also be able to lobby the FATF to make SR.VIII more proportionate to the needs of the NPO sector. If the Recommendation is seen to reflect the will of the state then it is more likely to be implemented. In terms of domestic NPO regulatory bodies, the England and Wales Charity Commission and the IRS charities division, amongst others, meet on a regular basis as the International Charity Regulators Forum. This forum could be utilized more by the FATF to improve SR.VIII and provide guidance.

The lack of a collective voice for the NPO sector can also offer an explanation for the limited compliance with SR.VIII. A similar situation resulted in the forming of the Wolfsberg Group ${ }^{87}$ by a group of leading banks. The banks' aim was to set up a lobbying collective in order to influence the future direction of

84 See FATF, above n 58, at 12.

85 ICFO, "Members," http://www.icfo.org/the-members/.

86 See: http://www.icfo.org/Uploaded_files/Zelf/ICFO\%20leaflet.pdf.

87 Wolfsberg Group, ‘Global Banks: Global Standards,' 2012, http://www.wolfsberg-principles. $\operatorname{com} /$. 
the FATF Recommendations. To be of similar success in the NPO sector, it would require a number of the larger NPOs to sign up.

The fourth and final variable is "national characteristics". Brown Weiss and Shelton identify the following parameters as bearing an influence in this section: the country's previous action concerning the subject of the agreement, history and culture, physical size and variation, and number of neighbouring countries; fundamental factors such as the economy, political institutions, and attitudes and values; and proximate factors such as administrative capacity, leadership, nongovernmental organisations, and knowledge and information. ${ }^{88}$ This section will not be further analysed as it would only serve to explain a specific country's reasons for low compliance as opposed to the wider trends that this article is looking at. Instead focus will be put in the following section on "compliance as a function of national intent and capacity" which can explain more broadly why a country or groups of countries fail to comply with SR.VIII.

\subsection{Compliance as a Function of National Intent and Capacity}

A set of parameters which were highlighted in the above "national characteristics" section were proximate factors. Brown Weiss and Shelton highlighted two factors which are related to these proximate factors being particularly important in explaining compliance with "soft law": intent of the state to comply; and the states capacity to comply. ${ }^{89}$

The functions of the FATF Recommendations "flexibility in meeting the obligations, and provisions for supervisory and monitoring mechanisms", 90 would imply that when states sign up they intend to comply as they are submitting themselves to assessment. So member states have freedom in terms of how to implement the measures of the Recommendation which may be appealing to them upon sign-up as they are only agreeing to broad principles or norms. But their compliance should be ensured by the supervisory and monitoring mechanisms addressed in the previous section.

Where debates on intention to comply are particularly interesting is with regard to the issue of the development and structure of the FATF Recommendations. It can be questioned whether states ever intended to comply with SR.VIII, it is one of the nine Special Recommendations introduced following $9 / 11$ to counter terrorist financing, and the majority of states would not have

88 See Brown Weiss and Shelton, above n 62, at 548.

89 Ibid., at 550-51.

90 Ibid., at 551-52. 
signed up to the FATF Recommendations with this in mind nor had a part to play in its introduction. At the time of its introduction membership of the FATF comprised 29 governments and two regional organisations ${ }^{91}$ that represented the major financial centres of the Americas, Europe and Asia. ${ }^{92}$ None of the FATF Style Regional Bodies ${ }^{93}$ had associate member status at the time of SR.VIII being introduced, in fact one: the Eurasian Group did not exist. This has now been alleviated with the FSRBs being granted associate member status of the FATF meaning that they get access to all meetings, and input on discussion and decisions. ${ }^{94}$ Indeed, of the 79 countries rated as non-compliant with SR.VIII only two (Brazil and Greece) would have had involvement in the development of SR.VIII, the others tend to fall within Africa, South America and the Middle East. These are the same countries that are likely to need NPO relief the most, and would have perhaps attempted to lower the burden of SR.VIII. If it was adopted by truly voluntary agreement then the impediments to compliance might be less. ${ }^{95}$ However, the fact that it has remained in the fourth round of mutual evaluations would suggest that the new wider involvement of associate members acknowledge the importance of a Recommendation on the NPO sector.

Brown Weiss and Shelton put particular emphasis on the states capacity as a factor for assessing compliance. ${ }^{96}$ They highlight a number of important factors that underpin capacity to comply, notably: an effective and honest bureaucracy, economic resources, and public support. ${ }^{97}$ Without these factors (or elements thereof) a state is likely to struggle to comply with the FATF Recommendations. In order to comply, a state is going to have to commit resources both in terms of finance and staff; this may be resources they do not have. Part of the reason for low levels of compliance with SR.VIII therefore could be that they have chosen to commit their resources to other areas of the FATF Recommendations, or

91 The European Commission and Gulf Co-operation Council.

92 FATF, Annual Report 2001-2002, June 2002, http://www.fatf-gafi.org/media/fatf/docu ments/reports/2001\%202002\%20ENG.pdf, 3.

93 Asia/Pacific Group on Money Laundering; Caribbean Financial Action Task Force; Council of Europe Committee of Experts on the Evaluation of Anti-Money Laundering Measures and the Fighting of Terrorism; Eurasian Group; Eastern and Southern Africa Anti-Money Laundering Group; Financial Action Task Force of Latin America; Inter Governmental Action Group against Money Laundering in West Africa; and, Middle East and North Africa Financial Action Task Force.

94 See FATF Annual Report: 2009-2010, above n 37, at Forward.

95 Peter M. Haas and Richard B. Bilder, "Compliance Theories Choosing to Comply: Theorizing from International Relations and Comparative Politics," in Commitment and Compliance: The Role of Non-binding Norms in the International Legal System, ed. Dinah Shelton (OUP, 2003), 53.

96 See Brown Weiss and Shelton, above n 62, at 552.

97 See Brown Weiss and Jacobson, above n 61, at 538. 
decided simply that the Recommendation does not warrant the use of their scarce resources.

That all members of either the FATF or a FATF-Style Regional Body have limited resources to counter terrorist financing can perhaps offer an explanation for the low levels of compliance with SR.VIII. Countries have to allocate their resources across the range of FATF Recommendations. Most countries can only dedicate a limited part of their resources and oversight to the NPO sector. Often the sector will consist of thousands of organisations that handle up to several percentages of the GDP of a country. ${ }^{98}$ The FATF foreseen these challenges and addressed them in the Interpretative Note to SR.VIII: "Countries should provide their appropriate authorities responsible for supervision, monitoring and investigation of their NPO sector with adequate financial, human and technical resources." 99 The difficulty with this is that there are no guidelines as to what amounts to "adequate". Therefore, what the FATF sees as adequate, and what the member jurisdiction sees as adequate are likely to be in conflict.

When considering the "adequate" allocation of resources, it is important to note that a state's anti-money laundering and counter-terrorist financing measures are all implemented on the basis of a risk-based approach. Therefore, their allocation of resources will be dependent upon the perceived risks emerging from the NPO sector, which as noted earlier could be low.

The lack of resources committed by states to regulating the NPO sector is a significant issue. The International Committee on Fundraising Organisations (ICFO) found that in the US the industry is lightly regulated due to a lack of resources. ${ }^{100}$ This is further compounded by many constitutional protections afforded to US charities, resulting in a vast number of organisations operating in the sector. The report further added that only those organisations which are exposed by media investigations or are otherwise the subject of numerous complaints get investigated. ${ }^{101}$ There is evidence to suggest that this problem is more widespread than just the US. ${ }^{102}$ What is clear then is that even where there are requirements to report on the spending of NPOs, such as in the US through Form 990, these are unlikely to trigger a terrorist financing investigation. Regulators do not have the resources to investigate each submitted report.

98 See FATF, above $\mathrm{n}$ 9, at 13.

99 See FATF, above n 38, at 28.

100 FATF, Third Mutual Evaluation Report on Anti-Money Laundering and Combating the Financing of Terrorism, United States of America, June 2006, http://www.fatf-gafi.org/media/ fatf/documents/reports/mer/MER\%20US\%20full.pdf, 249.

101 Ibid, at 250.

102 This has also been shown to be the case for England and Wales: https://www.gov.uk/ government/uploads/system/uploads/attachment_data/file/313371/tam_2012_13.pdf. 
Thus leading to a reactionary approach to regulation of the NPO sector, rather than proactively investigating.

The implementation of counter-terrorist financing measures in the NPO sector can have a greater impact on less developed countries. First, where it is discovered that even a small amount of funds have reached terrorist organisations, then the assets of the NPO may be frozen. ${ }^{103}$ This is not a desirable scenario for less developed countries as they are most likely the countries which need the charitable donations the most. The fact that only a small amount of the NPOs funds have been directed to terrorist purposes may lead to a lack of political will to highlight the issue. Second, where a NPO is either suspected of, or proved to have been involved in, terrorist financing has a significant impact on the NPO sector as a whole Roth, Greenburg and Wille have pointed out that NPOs identified as likely avenues of abuse have seen their activities diminish and their activities come under scrutiny. ${ }^{104}$ Third, those who donate to NPOs tend to become more cautious where terrorist financing is criminalized as it renders all those who knowingly contribute towards terrorist causes, directly or indirectly, liable to criminal charges. ${ }^{105}$ These three factors can all have an impact on NPOs operating in less developed countries. The fourth factor is that the counter-terrorist financing measures in the NPO sector may only affect legitimate NPOs. Fraudulent NPOs or those who have exploited NPOs for terrorist purposes will simply move on, either: reopening under a different name, abusing a different NPO, or reopening in a different jurisdiction. ${ }^{106}$ Ultimately, if a less developed country implements counter-terrorist financing measures in the NPO sector, it may just be hindering itself (and others) rather than preventing terrorism. This has been recognized as a key issue which needs to be addressed by the international framework. ${ }^{107}$

Even where less developed countries do want to implement counter-terrorist financing measures, they may have more difficulties complying than developed countries. The issue is twofold: they are likely to have less sophisticated administrative systems, and also fewer resources to devote to enforcement all hinder compliance. $^{108}$

103 See Muller, above n 4, at 263.

104 John Roth, Douglas Greenburg, and Serena Wille, 'National Commission on Terrorist Attacks Upon the United States: Monograph on Terrorist Financing,' 2004, http://govinfo. library.unt.edu/911/staff_statements/911_TerrFin_Monograph.pdf, 94 .

105 See World Bank, above n 17, at Ch. 3.

106 See Levitt, above $n 3$.

107 See Roth, Greenburg, and Wille, above n 104.

108 See Haas and Bilder, above n 95, at 46. 
To an extent, less developed countries can be assisted in their compliance with SR.VIII, either: financially, technically or through training. It has been stated that "technical capacity is a necessary although not sufficient condition to secure compliance with agreements that require technical policy implementation." 109 However, what such support will not solve is where a country simply does not want to implement SR.VIII, or does not feel that the benefits of implementing it outweigh the costs of complying, or that the cost of noncompliance is worth the benefits non-compliance affords.

\section{Compliance with other FATF Recommendations}

That $83 \%$ of FATF members are either partially compliant or non-compliant with SR.VIII is a significant statistic. However, in isolation it does not give an accurate representation of whether SR.VIII compliance levels are uniquely low. By investigating the compliance levels of the other FATF Recommendations, and comparing the findings to those for SR.VIII, it will highlight if there are any trends across the Recommendations as a whole. Due to the fact that the "partially compliant" countries can be judged to be so due to factors external to the specific Recommendation that is being assessed, this section will focus only on the "non-compliant" descriptor of each Recommendation. An example of this is that a country is likely to have customer due diligence measures in place for reasons other than counter-terrorist financing and therefore a country would not be assessed as "non-compliant" despite not enacting specific measures in relation to the assessed Recommendation.

The first comparison to make is with the other Special Recommendations, or more specifically the measures introduced following 9/11 which focus on counter-terrorist financing. The third round of Mutual Evaluation Reports represents the first opportunity to assess individual countries compliance with them. Most notable is that five of the 9 Special Recommendations have very similar levels of non-compliance, ranging between $36 \%-45 \%$. SR.III on "freezing and confiscating terrorist assets" has a higher level of non-compliance at $46.7 \%$. When partial compliance is added to non-compliance the outcome remains similar. This time four of the Special Recommendations are rated between $73-83 \%$. SR.VIII is a

109 See: Beth A. Simmons, "International Law and State Behaviour: Commitment and Compliance in International Monetary Affairs.” American Political Science Review 94(4) (2000): 819, 819; and Peter M. Haas, Robert O. Keohane, and Marc A. Levy, Institutions for the Earth: Sources of International Environmental Protection (1st edn., MIT Press, 1993). 
slight outlier at $87.2 \%$. Furthermore, only one of the 9 Special Recommendations has more than $5 \%$ of countries being rated as "compliant". These statistics would appear to suggest that SR.VIII is not alone, amongst other counterterrorist financing Recommendations, in having low levels of compliance.

This raises the potential at least that it is the wider approach of the FATF in dealing with terrorist financing that is flawed. Indeed this is not a new argument, and is based around the idea that the international anti-money laundering framework is not an appropriate model to adopt for counter-terrorist financing. The main reason for this is that the motivations between these two financial crimes are very different. With money laundering the funds always originate from illegitimate activities, the launder then attempts to "clean" their ill-gotten gains so it can be used without alerting others to its origins. Detection arises when there is suspicion as to where the money has come from. The problem when applying this approach to counter-terrorist financing is that the terrorist group vary in their organisational form and how they raise, store and move their funds. Whilst the aim of terrorist financing is still to channel funds to an end person or organisation, ${ }^{110}$ only occasionally will there be a need to go through the laundering process. Funds channelled to terrorist purposes can be both licit and illicit. ${ }^{111}$ It has been noted that funds often originate from legitimate sources meaning that enforcement authorities can almost never detect their final destination, unless a connection can be made between a suspected individual and a bank account or other financial transaction. ${ }^{112}$ The use of legitimate sources of funding is of increasing use in the European Jihadist financing. ${ }^{113}$ Linked to this is an increase in self-funding due to the decreasing costs of terror, which makes it very hard for terrorist funds to be identified. ${ }^{114}$ A further difficulty is the wide variety of sources of funding that terrorist organisations have meaning they are not reliant on one income stream. ${ }^{115}$ The variety in sources of funding makes the battle against terrorist financing a difficult one.

110 Angela S. M. Irwin, Kim-Kwang R. Choo, Lin Liu, “An Analysis of Money Laundering and Terrorism Financing Typologies.” Journal of Money Laundering Control 15(1) (2011): 85, 87.

111 Jeanne K. Giraldo and Harold A. Trikunas, "The Political Economy of Terrorism Financing," in Terrorism Financing and State Responses: A Comparative Perspective, ed. Jeanne K. Giraldo and Harold A. Trikunas (Stanford University Press, 2007), 15.

112 See Bantekas, above n 23, at 320.

113 Loretta Napoleoni, "The Evolution of Terrorist Financing Since 9/11: How the New Generation of Jihadists Fund Themselves," in Terrornomics, ed. Sean S. Costigan and David Gold (Abingdon, Oxon, Great Britain: Ashgate Publishing, 2007), 17.

114 Ibid at 20.

115 See Giraldo and Trikunas, above n 111, at 7-10. 
As an example of how unsuccessful counter-terrorist financing strategies have been, it is worthy of note that as of 2007 only around \$200 million of terrorist funds had been frozen around the world. ${ }^{116}$ It needs to be remembered however that the FATF mutual evaluation reports focus on compliance with their Recommendations, so whilst the above analysis provides a rationale for the failings of the international counter-terrorist financing framework, it does not in itself explain the poor compliance levels. Of course, it could be argued that the low compliance is a result of states not believing that the Recommendations are effective, however representatives of their countries play a large part in the development of FATF Recommendations and this concern should be addressed at that stage. As well as this, it has been stated that global terror financing still originates from criminal and illegal activities, which range from petty crime to large-scale fraud. ${ }^{117}$ This means that there is still space for counter measures based on identifying illegitimate funds.

One area to be ruled when considering the low levels of compliance with the terrorist financing Recommendations is the definitional saga surrounding "terrorists" and "freedom fighters". Bantekas acknowledged the difficulty in defining terrorism and in turn implementing counter-terrorist financing measures. ${ }^{118}$ However, these Recommendations have stayed in the assessment for the fourth round of mutual evaluations and only assess whether a country has implemented them not whether the Recommendation is successful.

For the fourth round of Mutual Evaluation Reports, SR.VIII has been fully incorporated into the 40 Recommendations as Recommendation 8. It will be interesting to track the changes to see whether compliance levels improve. If all of the original Special Recommendations improve then it would perhaps suggest that time was required for them to be understood fully and implemented rather than a problem inherently with the FATF counter-terrorist financing Recommendations. But, most interesting will be to see how compliance levels for Recommendation 8 stand against the third round statistics for SR.VIII, in order to see whether subsequent developments have had an effect. As outlined in preceding sections the FATF has sought to improve compliance in the area in various ways: new Best Practice papers, consultation with the sector, and improvements to the Interpretative Note. If this does not see an improving level of compliance then it may suggest that the problem lies with states' commitment to the Recommendation itself, rather than the Recommendation being poorly executed at FATF level.

116 See Napoleoni, above n 113, at 17.

117 See Napoleoni, above n 113, at 17.

118 See Bantekas, above n 23, at 315. 
Table 1: Partial and non-compliance with non-financial sector Recommendations.

\begin{tabular}{|c|c|c|c|}
\hline Recommendation & $\begin{array}{r}\text { Non-compliance } \\
(\%)\end{array}$ & $\begin{array}{r}\text { Partial } \\
\text { compliance } \\
(\%)\end{array}$ & $\begin{array}{r}\text { Combined partial } \\
\text { and non-compliance } \\
(\%)\end{array}$ \\
\hline $\begin{array}{l}\text { R.8-“new technologies and non-face } \\
\text { to face business" }\end{array}$ & 38 & 33 & 71 \\
\hline $\begin{array}{l}\text { R.16-“designated non-financial } \\
\text { businesses and professions" }\end{array}$ & 63.3 & 33.3 & 96.7 \\
\hline $\begin{array}{l}\text { R.20-“non-financial businesses and } \\
\text { professions (other than DNFBP)" }\end{array}$ & 17.8 & 20.5 & 38.3 \\
\hline $\begin{array}{l}\text { SR.VI-“anti-money laundering } \\
\text { requirements for money value } \\
\text { transfer services" }\end{array}$ & 35.6 & 38.3 & 73.9 \\
\hline SR.VII-“wire transfers" & 45 & 32.8 & 77.8 \\
\hline
\end{tabular}

The second comparison to be made is with the other non-financial sector Recommendations. As can be seen from Table 1 compliance levels are low. The only anomaly is Recommendation 20, which has a rating of just under $40 \%$ for partial and non-compliance; however, this is still a relatively high figure.

As Table 1 shows the other non-financial sector Recommendation's all have a non-compliance rating of over 35\%, with Recommendation 16 in particular standing out with $63.3 \%$ non-compliance. Overall, these statistics for non-financial sector Recommendations highlight that maybe the FATF would benefit from outside assistance on developing measures in other sectors, and that rather that support structure is somewhat lacking. It shows that SR.VIII is not a unique challenge facing the FATF, and provides another theme of potential weakness in the FATF's expertise.

As a contrast, Table 2 shows that non-compliance is not a significant issue for all FATF Recommendations. In particular non-compliance with these long standing, and what could be categorized as core, FATF Recommendations is significantly lower than non-compliance with the Recommendations in Table 1.

It is apparent that the Recommendation with the highest level of noncompliance is Recommendation 10 which comes in at $7.8 \%$, significantly less than the Recommendations mentioned earlier in this section. There are a number of factors that lead to this dichotomy: first, the measures are long-standing; and second, they are the fundamental measures relating to anti-money laundering and counter-terrorist financing. Some of them such as Recommendation 1 and Recommendation 35 make reference to international conventions which are 
Table 2: Non-compliance with longstanding Recommendations.

\begin{tabular}{lr}
\hline Recommendation & $\begin{array}{r}\text { Non-compliance } \\
\text { (\%) }\end{array}$ \\
\hline R.1-“money laundering offence" & 7.2 \\
R.2-“the mental element of the money laundering & 3.3 \\
offence and corporate liability" & \\
R.10-“record keeping" & 7.8 \\
R.14-“protection and tipping off" & 6.1 \\
R.28-“powers of competent authorities - compulsory & 0.5 \\
production orders" & 6.5 \\
R.35-“international conventions" & \\
\hline
\end{tabular}

"hard law" meaning once signed they have to be implemented into national law, this strengthens compliance with the relevant soft law measure contained in the FATF Recommendations.

Overall, these statistics highlight that SR.VIII is not unique in terms of its low levels of compliance; other Recommendations are equally bad, if not worse. But, given its susceptibility to abuse, the NPO sector remains an important one to regulate. The fact that, as highlighted, some Recommendations were achieving high levels of compliance underlines that the issue with compliance is not with the FATF Recommendations as a whole. There are two main themes that emerge from this section. First, the Special Recommendations are weak in terms of compliance, but, this may be a result of them being relatively new and previously unassessed. Second, the FATF has an issue with regards to compliance with Recommendations which have a focus away from the financial sector, and that perhaps they need additional expertise and guidance in these areas. Each sector will have its own issues and institutions involved in these sectors are best placed to advise the FATF of these.

\section{Conclusion}

Terrorist financing through the NPO sector is one of a number of avenues open to channel funds to terrorist groups. Whilst there is a great deal of dispute as to the volume of terrorist financing occurring through the NPO sector, what is not in doubt is that it is susceptible to abuse. As a result, and owing to the increased political will to counter terrorist financing following 9/11, the Financial Action Task Force developed SR.VIII. 
SR.VIII takes the Financial Action Task Forces outside its usual anti-money laundering and counter-terrorist financing confines in the financial sector, and provides measures to tackle abuse of NPOs. Hayes in studying the Recommendation found that $85 \%$ of countries were either partially or noncompliant, further investigation for this article discovered that on a greater range of countries that statistic stayed similar at $83 \%$. The figure is significant and suggests major deficiencies with the Recommendation.

This article adopted a two pronged approach to investigating the statistic on compliance with SR.VIII: first, it sought to appreciate why partial and noncompliance with SR.VIII was so high; and second, to ascertain whether SR.VIII was alone in having such a high level of partial and non-compliance. In respect of the first point, an approach was adopted that has been used to assess compliance with various international "soft law" instruments, the finding was that there are various interacting factors which contribute to $83 \%$ of countries being found partially or non-compliant with SR.VIII. In terms of the factors affecting compliance it was found that the FATF's lack of expertise in their area, and their lack of engagement with the sector (until recently) could be seen as contributing factors to the low compliance. It was suggested this was further compounded by the lack of a bona fide international charity regulator or an international lobbying group for the NPO sector, albeit the existence of the International Charity Regulators Forum and the ICFO were recognized as partially alleviating this. Further, continuing typology reports will improve the FATF's own knowledge of the area.

Some factors were dismissed as issues affecting compliance with SR.VIII. It was found that the large membership cannot be considered to result in low compliance as other Recommendations are similarly poorly implemented. Whilst, with regards to mechanisms used to induce compliance, it was noted that SR.VIII had never been through the Mutual Evaluation process before. As a result, there had not been the opportunity for formal FATF evaluation and feedback with resulting pressure on improved compliance, nor could the FAFT impose sanctions to improve compliance. The third round of Mutual Evaluations was the first opportunity for the FATF to see an accurate snapshot of poor compliance with SR.VIII.

In terms of compliance as a function of state capacity intent, these factors play a significant role in explaining low compliance with SR.VIII. It was found that of the 79 non-compliant countries, 77 of them had no role in the development of SR.VIII. This is mainly because at the stage of drafting the Recommendation FATF-Style Regional Bodies were not Associate Members of FATF and so had no involvement in the development of Recommendations. It was further noted that the majority of those 77 countries were located in those 
areas most likely to need NPO relief and therefore most likely to be effected by implementing restrictive NPO regulation. Another significant finding was that there is limited resources to tackle terrorist financing and the risk-based approach means that countries may choose to focus their resources elsewhere, where the results will be seen, therefore leading to low compliance. It was suggested that less developed countries are more susceptible to this approach.

As to the second point, the article compared SR.VIII compliance with: first, the other Special Recommendations; second, other recommendations not focussed on the financial sector; and finally; against the more long standing and important Recommendations. This comparison found that SR.VIII was not alone in having high levels of non-compliance. The other Special Recommendations and the non-financial sector Recommendations, for the most part, have lower levels of compliance. At this stage it was recognised that there are issues with regards to implementing the FATF's anti-money laundering model with regards to counter-terrorist financing, particularly where the funds are legitimate or where self-financing is taking place. But it was noted that illegitimate sources are still used also and so the anti-money laundering model is still of some use. The section also recognised the difficulty of the definitional saga surrounding "terrorists" and "freedom fighters". For both of these it was noted that the mutual evaluation report is not measuring the efficiency of the measures implemented in that State, rather it is measuring if sufficient measures have been introduced to meet the aims of the Recommendation. With regards to the Recommendations that can be considered as being more pivotal to the anti-money laundering and counter-terrorist financing regime all have significantly higher levels of compliance. Highlighting the issues that cause partial and non-compliance with SR.VIII may also cause issues for other Recommendations. Ultimately, the FATF Recommendations are a developing system, such that over time compliance will improve, as knowledge increases and as the countries go through more mutual evaluations. 